\title{
Effect of STEAM Education Program Using Flexible Display
}

\author{
Hye-Sun Song, Seok-Hee Kim, Yeon-Jung Song, Peu-ReunYoo, Ji-Yeong Lee, and Hyeonchang Yu
}

\begin{abstract}
The need for STEAM education has increased as an educational law of Mathematics, Science and Information Education was promulgated in April 2018, and applied to the revised curriculum of 2015 in Korea.

Development of a STEAM program using flexible display expected to be a suitable tool for mathematics, science and software classes. In this research, we developed Flexible Display Programming tool based on scratch 2.0. Based on that software we designed STEAM educational program for elementary, middle school students.

Satisfaction measurement of this program shows that there is enhancement of the attitude to science and mathematics. Moreover, qualitative measurement confirms the possibility of the suggested method of education in Science, Technology, Engineering, Arts and Mathematics.
\end{abstract}

Index Terms -STEAM education, flexible display, software, arduinoscratch, mathematics, scaffolding.

\section{INTRODUCTION}

Visual information can deliver a large amount of information to the human brain. Flexible display is called "dream display device". It is considered the third-generation display device following the first-generation CRT and second-generation flat display devices. It can be used in a variety of situations, such as next-generation smart phones and wearable computing. Therefore, the experience of solving real-life problems using this flexible display is important in understanding the world to come.

In April 2018, Korean Government published the law which promotes Mathematics, Science and Software Education [1]. The law aims to foster creative talent through convergence of two or more subjects. STEAM education is recognized as a converged problem-solving method. It is also considered as a way to develop creative problem-solving skills in the future. People believe that STEAM education showed the possibility to develop creative problem-solving skills through a convergence of mathematics, science, and software education programs. The study revealed that elementary school teachers' level of STEAM awareness was low in 600 elementary schools. Moreover only one percent of teachers has experience of STEAM classes. Regarding the result, the teachers' statements showed that it is because of the burden of preparing the class and the barriers to teachers and students' technology and related educational tools.

Manuscript received December 17, 2018. This work was supported by the Korea Foundation for the Advancement of Science \& Creativity (KOFAC) grant funded by the Korean Government (MOE).

The authors are with Hoeryong Elementary School, Korea (email: 0606shs@naver.com, riemann@korea.ac.kr, ongyjt@korea.kr, ypr00@hanmail.net, ljy925@korea.kr,yuhc@korea.ac.kr).
Therefore, this study aims to develop the programming environment based on scratch 2.0 which provides scaffolding for Flexible Display programming. So, programming novice can program the Flexible Display.

\section{THEORETICAL BACKGROUND}

\section{A. STEAM Education}

STEM is the term first used by the National Science Foundation (NSF) as an abbreviation for Science, Technology, Engineering and Mathematics. STEM has occupied important position in reforming science education worldwide today since it frequently appears in educational policy and educational research. John [2] (2000) noted that STEM education neglected the area of cognitive science related to creativity, and arts [3]. Maes(2010) also stated that arts and humanities must be included in order for the results of the convergence of science, technology, engineering and mathematics to realize individual creativity [4]. So, the STEAM education added Art to STEM.

STEAM education was proposed as an important educational policy direction for solving the low motivation for science learning and the phenomenon of avoiding science and engineering [5]. Regarding teaching and learning methods for STEAM education, Sanders (2009) emphasized the importance of an integrated approach based on mutual communication and cooperation among subjects, not on individual education in science, technology, engineering and mathematics [6].

The "Learning By Design" educational program, developed by the American Society of Engineering Educators and supported by NASA and the US National Science Foundation, is a practical problem-oriented science and mathematics application program centered on content and problem solving processes in technology and engineering [7]

\section{B. Flexible Display}

Flexible Display allows to be used in a bendable form. WS2812 and SK6812, commonly used as LED driver chips in Flexible Display. It has the following features.

- It is possible to be controlled with 4 pins.

- The price is very cheap.

- Various libraries have been developed.

- Refresh rate is not high.

This research is based on flexible displays based on WS2812 and SK6812 chip, which is inexpensive and it has 4 connection pins.

\section{Flexible Display Programming Environment}

Flexible Display using Open hardware can be programmed 
using $\mathrm{C}++$. Fig. 1 shows the Flexible Display programming screen.

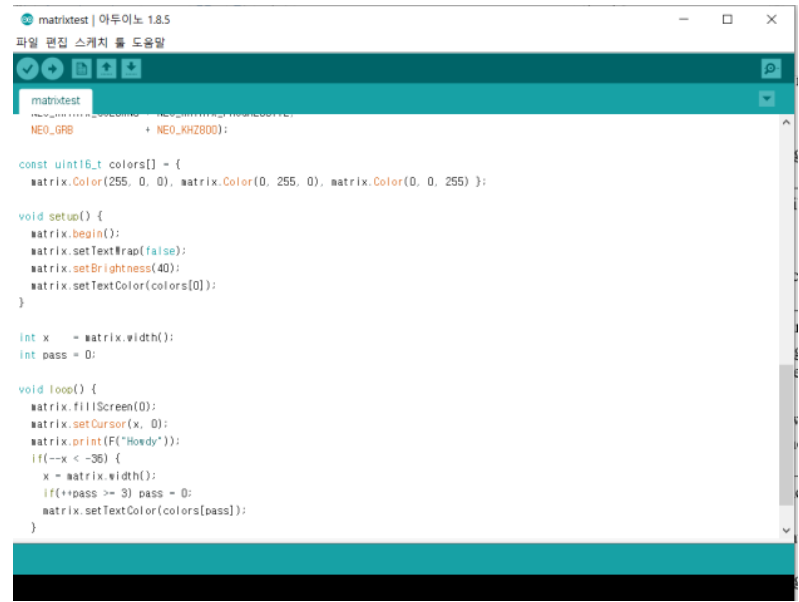

Fig. 1. Text based flexible display programming.

However, it is not suitable for programming beginners. Therefore, in this research, we develop a block-type programming interface for open hardware.

\section{RESEARCH METHOD}

\section{A. Research Subjects and Evaluation Methods}

The subjects of this study are 790 elementary and junior high school students.

Table I shows the study subjects and the application period of the developed education program. STEAM standard attitude change evaluation is applied before and after evaluation method. The evaluation period is from May to June, and the post evaluation is conducted within one month after the program is applied.

TABLE I: RESEARCH SUBJECTS AND WHEN TO APPLY THE TRAINING

\begin{tabular}{|c|c|c|c|}
\hline \multicolumn{4}{|c|}{ PROGRAM } \\
\hline division & $\begin{array}{l}\text { Applicable } \\
\text { grade }\end{array}$ & $\begin{array}{c}\text { Number of } \\
\text { people }\end{array}$ & $\begin{array}{l}\text { Application } \\
\text { date }\end{array}$ \\
\hline $\begin{array}{c}\text { elementary } \\
\text { Grades } 1 \text { and } 2\end{array}$ & 1 Grade & 90 & \multirow{4}{*}{$\begin{array}{c}\text { September } \\
\text { to } \\
\text { November }\end{array}$} \\
\hline $\begin{array}{c}\text { elementary } \\
\text { Grades } 3 \text { and } 4\end{array}$ & 4 Grade & 240 & \\
\hline $\begin{array}{c}\text { elementary } \\
\text { Grades } 5 \text { and } 6\end{array}$ & $\begin{array}{c}\text { Grades } 5 \\
\text { and } 6\end{array}$ & 120 & \\
\hline middle School & 1 Grade & 340 & \\
\hline \multicolumn{2}{|c|}{ Sum } & 790 & \\
\hline
\end{tabular}

\section{B. Education Program}

STEAM program using Flexible Display is shown on Table II. This table show the details. It contains main activities of the grade group. The learning activity take 3 hours.

Learning activities emphasize the creativity of students.
Students make and create with flexible display. According their purpose, they should code the flexible display.

TABLE II: EDUCATION PROGRAM

\begin{tabular}{|c|c|c|}
\hline $\begin{array}{l}\text { Grade } \\
\text { group }\end{array}$ & Subject & Main activity \\
\hline $\begin{array}{c}\text { elemen } \\
\text { tary } \\
\text { Grades } \\
1 \text { and } 2\end{array}$ & $\begin{array}{c}\text { Create a shape } \\
\text { with a light } \\
\text { point. }\end{array}$ & $\begin{array}{l}\text { - Find } \bigcirc, \square, \triangle \text { shapes and understand } \\
\text { features. } \\
\text { - Looking for } \bigcirc, \square, \triangle \text { shapes in your life. } \\
\text { - Expressing } \bigcirc, \square, \triangle \text { shapes in a grid. } \\
\text { - Understand the features of the } \bigcirc, \square, \triangle \\
\text { shapes. } \\
\text { - Create the } \bigcirc, \square, \triangle \text { shapes. } \\
\text { - Understand the concept of digital pixel. } \\
\text { - Identify the pixel as a bright point. } \\
\text { - Draw } \bigcirc, \square \text {, and } \triangle \text { with light points. } \\
\text { - Create various patterns with the } \bigcirc, \square, \triangle \\
\text { shapes made of light points. } \\
\text { - Decorate your classroom with light points. } \\
\text { - Use } \bigcirc, \square, \triangle \text { shapes to create a variety of } \\
\text { creative shapes. } \\
\text { - Enjoy classrooms decorated with } \bigcirc, \square, \triangle \\
\text { shapes. } \\
\text { - Respect each other's work and give positive } \\
\text { feedback. }\end{array}$ \\
\hline $\begin{array}{l}\text { elemen } \\
\text { tary } \\
\text { Grades } \\
3 \text { and } 4\end{array}$ & $\begin{array}{c}\text { Draw shapes } \\
\text { on Flexible } \\
\text { Display. }\end{array}$ & $\begin{array}{l}\text { - Learn about the features of flexible displays } \\
\text { through storytelling } \\
\text { - Find out the difference between a bending } \\
\text { smartphone and a commonly used } \\
\text { smartphone. } \\
\text { - Draw Points, Straight Lines, and Diagonals } \\
\text { on Flexible Display. } \\
\text { - Learn the concept of shapes by looking for } \\
\text { regularity and counterclaiming. } \\
\text { - Learn about the different rectangular } \\
\text { features and draw them on a flexible display. } \\
\text { - Learn more about the various pattern } \\
\text { designs. } \\
\text { - Create beautiful polygon patterns through } \\
\text { programming. } \\
\text { •Create a work by attaching a flexible display } \\
\text { to other objects } \\
\text { •Watch other friends' works and find out } \\
\text { what shapes they used. }\end{array}$ \\
\hline $\begin{array}{l}\text { elemen } \\
\text { tary } \\
\text { Grades } \\
5 \text { and } 6\end{array}$ & $\begin{array}{l}\text { Find the } \\
\text { width of a } \\
\text { shape with a } \\
\text { Flexible } \\
\text { Display. }\end{array}$ & $\begin{array}{l}\text { - Learn what Scratch code Blocks mean. } \\
\text { - Draw multiple lines, rectangles with scratch } \\
\text { code blocks } \\
\text { - Create a Rectangular shape using the } \\
\text { Scratch Command Blocks } \\
\text { - Find out how to obtain a rectangular width } \\
\text { by creating a rectangle on a flexible display. } \\
\text { • Create your own creative pedestrian traffic } \\
\text { lights by utilizing different types of } \\
\text { rectangular shapes using a flexible display. } \\
\text {-By applying SCAMPER techniques such as } \\
\text { substitution, coupling, application, removal, } \\
\text { modification, enlargement, shrinkage and } \\
\text { rearrangement, plan and create my own } \\
\text { creative pedestrian traffic light. } \\
\text { •Evaluate your friends' work to see what's } \\
\text { good and what's to be complemented. }\end{array}$ \\
\hline
\end{tabular}




\begin{tabular}{|c|c|c|}
\hline $\begin{array}{l}\text { Middle } \\
\text { school } \\
\text { grade } 1\end{array}$ & $\begin{array}{c}\text { Making } \\
\text { works using } \\
\text { principles of } \\
\text { light synthesis }\end{array}$ & $\begin{array}{l}\text {-Draw shapes (triangle or square, } \\
\text { rectangular) on a flexible display and know } \\
\text { the scratch code blocks that fills the face with } \\
\text { color. } \\
\text { - Check each color using the RGB value of the } \\
\text { scratch code blocks. } \\
\text { - Create a program that is illuminated by a } \\
\text { certain value of the sound sensor. } \\
\text { - To change the sound sensor reading of the } \\
\text { scratch code blocks and to check the LED's } \\
\text { on, off } \\
\text { - Create LED wearables that respond } \\
\text { according to the size of sound by group. } \\
\text { - Experiment with principle of light mixing } \\
\text { using pixel programming of Flexible Display. } \\
\text { - Understand the principle of making color in } \\
\text { digital display technology } \\
\text { - Experiment with principle of light mixing } \\
\text { using pixel programming of Flexible Display. } \\
\text { - Understand the principle of making color in } \\
\text { digital display technology. }\end{array}$ \\
\hline $\begin{array}{l}\text { Exam-f } \\
\text { ree } \\
\text { semest } \\
\text { er }\end{array}$ & $\begin{array}{c}\text { Send a } \\
\text { message } \\
\text { expressing } \\
\text { your heart to } \\
\text { the board by } \\
\text { mobile }\end{array}$ & $\begin{array}{l}\text { - Design various messages to communicate } \\
\text { with friends. } \\
\text { - Know what Scratch command blocks mean } \\
\text { - Click on each of the scratch command } \\
\text { blocks to see what happens. } \\
\text { - Draw multiple types of lines with scratch } \\
\text { command } \\
\text { - Draw lines with different colors and } \\
\text { positions } \\
\text { - Know the block where the scratch } \\
\text { command block fills the face with color } \\
\text { - Click on the scratch command block to see } \\
\text { how the face is filled } \\
\text { - Understanding blocks for sending text to } \\
\text { mobile devices using Scratch } \\
\text { - Try running an example and understand the } \\
\text { meaning of the block } \\
\text { - Try using Scratch to practice sending text } \\
\text { messages to your mobile device } \\
\text { - Using a mobile device to send an English } \\
\text { message with Scratch programming }\end{array}$ \\
\hline
\end{tabular}

\section{Flexible Display Programming Tool}

The Flexible Display programming tool consists of 22 blocks. Blocks can be classified into four types.

They consist of declaration of flexible display type, drawing figures, writing a sentence and effecting to Flexible Display.

Fig. 2 shows an example of the Flexible Display programming block and the execution result.

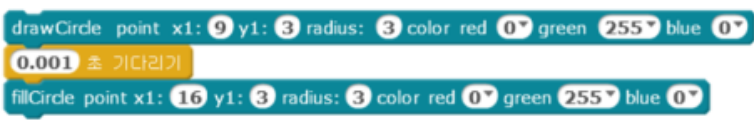

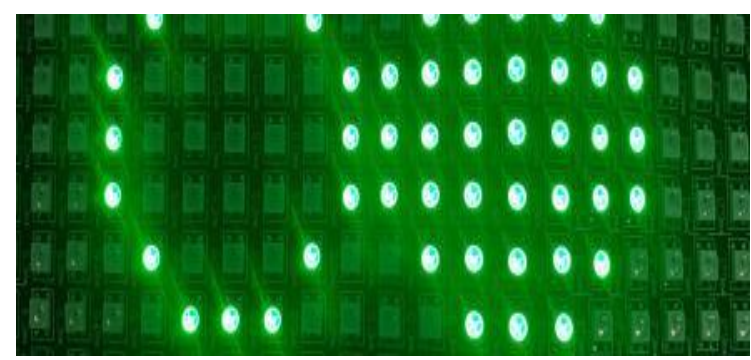

Fig. 2. Block code and execution result.

\section{CONCLUSION AND DISCUSSION}

\section{A. Satisfaction Measurement Results [7]}

Table III is the result of a paired-test on the pre - and post examination of attitude changes to science, mathematics through a steam program.

The significance level is $\left[P^{*}<.05\right]$.The test showed a significant result in the questions 5,8, 23, 35, 36, and 40. "I like science." and "Knowledge of mathematics is helpful in everyday life." have shown that we have achieved the original purpose of STEAM program.

Especially, we can see the characteristics of the STEAM education program through the results that mathematics and science have improved at the same time.

The results of questions 34 and 40 showed that students did not like mathematics, but they like the mathematics contents of this STEAM education program.

\begin{tabular}{|c|c|c|c|c|c|}
\hline \multirow[b]{2}{*}{$\mathrm{n}$} & \multirow[b]{2}{*}{ Question } & \multicolumn{4}{|c|}{ Paired t-test } \\
\hline & & Mean & $\begin{array}{l}\text { Standard } \\
\text { Deviation }\end{array}$ & $t$ & $\begin{array}{c}p- \\
\text { value }\end{array}$ \\
\hline 1 & I like the contents of science class. & -0.17 & 0.98 & -1.97 & 0.051 \\
\hline 2 & $\begin{array}{l}\text { I am confident that I can understand the } \\
\text { contents of math. }\end{array}$ & -0.04 & 1.18 & -0.37 & 0.712 \\
\hline 3 & $\begin{array}{c}\text { I like math activities (such as math } \\
\text { experience activities, solving math quiz } \\
\text { questions, or reading math-related } \\
\text { books). }\end{array}$ & -0.16 & 1.33 & -1.38 & 0.170 \\
\hline 4 & It's great to have a science-related job. & -0.12 & 1.06 & -1.24 & 0.217 \\
\hline 5 & I enjoy studying science. & -0.21 & 1.05 & -2.25 & $0.026^{*}$ \\
\hline 6 & $\begin{array}{l}\text { I am confident that I can understand the } \\
\text { contents of science. }\end{array}$ & -0.08 & 1.02 & -0.86 & 0.390 \\
\hline 7 & $\begin{array}{l}\text { I enjoy finding and reading information } \\
\text { or books about science. }\end{array}$ & -0.12 & 1.38 & -1.02 & 0.310 \\
\hline 8 & I like science. & -0.22 & 1.12 & -2.19 & $\mathbf{0 . 0 3}^{*}$ \\
\hline 9 & $\begin{array}{l}\text { I am interested in a job related to } \\
\text { mathematics. }\end{array}$ & -0.07 & 1.44 & -0.55 & 0.584 \\
\hline 10 & $\begin{array}{c}\text { I enjoy science-related activities (visit } \\
\text { science museums, participate in } \\
\text { scientific events, and read } \\
\text { science-related books). }\end{array}$ & -0.06 & 1.21 & -0.58 & 0.562 \\
\hline 11 & $\begin{array}{c}\text { I share my science experiment tool with } \\
\text { other friends. }\end{array}$ & -0.08 & 0.84 & -1.04 & 0.299 \\
\hline 12 & $\begin{array}{c}\text { It is important to share ideas with your } \\
\text { friends when you are gathering in } \\
\text { science class. }\end{array}$ & -0.08 & 0.87 & -1.01 & 0.314 \\
\hline 13 & $\begin{array}{l}\text { Studying science will help you study in } \\
\text { middle and high schools in the future. }\end{array}$ & -0.15 & 0.93 & -1.89 & 0.061 \\
\hline 14 & I like the contents of math class. & -0.14 & 1.30 & -1.22 & 0.226 \\
\hline 15 & $\begin{array}{l}\text { I listen carefully to my friend's } \\
\text { presentation in math class. }\end{array}$ & -0.07 & 1.20 & -0.66 & 0.513 \\
\hline 16 & $\begin{array}{c}\text { I enjoy finding and reading information } \\
\text { or books about math. }\end{array}$ & -0.22 & 1.48 & -1.72 & 0.088 \\
\hline 17 & Math helps to study other subjects. & 0.11 & 1.23 & 1.00 & 0.322 \\
\hline
\end{tabular}




\begin{tabular}{|c|c|c|c|c|c|}
\hline 18 & $\begin{array}{c}\text { I respect the opinion of my friend who } \\
\text { has different opinions in math class. }\end{array}$ & -0.12 & 1.06 & -1.33 & 0.187 \\
\hline 19 & It's wonderful to have a job in math. & 0.02 & 1.31 & 0.20 & 0.841 \\
\hline 20 & $\begin{array}{c}\text { I also take a deep look at other friends' } \\
\text { positions when I make an opinion in } \\
\text { science class. }\end{array}$ & -0.12 & 0.93 & -1.51 & 0.135 \\
\hline 21 & I enjoy studying math. & 0.04 & 1.48 & 0.30 & 0.768 \\
\hline 22 & $\begin{array}{l}\text { I actively share my opinions with my } \\
\text { friends in math class. }\end{array}$ & -0.01 & 1.26 & -0.07 & 0.945 \\
\hline 23 & $\begin{array}{l}\text { I actively share my opinions with my } \\
\text { friends in science class. }\end{array}$ & -0.23 & 1.16 & -2.27 & $0.025^{*}$ \\
\hline 24 & I think science is easy. & 0.02 & 1.37 & 0.19 & 0.848 \\
\hline 25 & $\begin{array}{c}\text { I actively express my thoughts in math } \\
\text { class. }\end{array}$ & -0.05 & 1.34 & -0.46 & 0.647 \\
\hline 26 & $\begin{array}{l}\text { I listen carefully to my friend's } \\
\text { presentation in science class. }\end{array}$ & -0.09 & 0.99 & -1.06 & 0.291 \\
\hline 27 & $\begin{array}{l}\text { I am confident that I can solve math } \\
\text { problems well. }\end{array}$ & -0.10 & 1.39 & -0.82 & 0.414 \\
\hline 28 & $\begin{array}{l}\text { I have a quick understanding of the } \\
\text { math content. }\end{array}$ & -0.10 & 1.39 & -0.82 & 0.414 \\
\hline 29 & Science helps you study other subjects. & -0.02 & 1.07 & 0.25 & 0.806 \\
\hline 30 & $\begin{array}{l}\text { I have a quick grasp of the contents of } \\
\text { science. }\end{array}$ & -0.06 & 1.19 & -0.59 & 0.555 \\
\hline 31 & $\begin{array}{c}\text { Knowledge of science is helpful in } \\
\text { everyday life. }\end{array}$ & -0.05 & 1.09 & -0.56 & 0.573 \\
\hline 32 & $\begin{array}{c}\text { It is important to share ideas with your } \\
\text { friends when you are gathering in math } \\
\text { class. }\end{array}$ & -0.01 & 1.15 & -0.08 & 0.939 \\
\hline 33 & $\begin{array}{l}\text { Studying math will help you study in } \\
\text { middle and high school in the future. }\end{array}$ & 0.05 & 1.18 & 0.52 & 0.603 \\
\hline 34 & I like math. & 0.01 & 1.60 & 0.06 & 0.956 \\
\hline 35 & $\begin{array}{c}\text { I am confident that I can solve science } \\
\text { problems well. }\end{array}$ & -0.23 & 1.20 & -2.19 & 0.031* \\
\hline 36 & I am interested in a career in science & -0.28 & 1.31 & -2.41 & $0.018^{*}$ \\
\hline 37 & $\begin{array}{l}\text { I actively express my thoughts in } \\
\text { science class. }\end{array}$ & -0.17 & 1.20 & -1.61 & 0.109 \\
\hline 38 & I think math is easy. & 0.11 & 1.52 & 0.81 & 0.421 \\
\hline 39 & $\begin{array}{c}\text { I also take a deep look at other friends' } \\
\text { positions when I make an opinion in } \\
\text { math class. }\end{array}$ & -0.05 & 1.16 & -0.45 & 0.651 \\
\hline 40 & $\begin{array}{c}\text { Knowledge of mathematics is helpful in } \\
\text { everyday life. }\end{array}$ & -0.38 & 1.35 & -3.24 & $0.002^{*}$ \\
\hline
\end{tabular}

\section{B. Discussion}

After applying the program, the students were interviewed as follows.

"Combining a science and software class was interesting experiences, so we became interested in Flexible Display."

"Although I had a hard time at the class since it was the first time. After I had experienced it, I felt like growing up."

"It's fun to actually experience the technology we've only seen in movies, and I'm interested in programming."

"It was amazing for me to code Flexible Display myself. It was challenging task for me, but it was good time when the work was completed."

"I was amazed to see the Flexible LED."

"When I am coding myself, it was fun to see a variety of lights from the Flexible Display."

By the students' interview, we conclude that students extend their understanding of Flexible Display and confirm that they accepted it as a new way of learning.

The results of statistical analysis and qualitative measurement show that Flexible Display have an impact on STEAM. However, further studies are needed on the effects of long-term classroom application, gender differences.

\section{Teacher's Opinions after Applying Steam Program}

After applying the program, the teachers were interviewed as follows.

"It was half-believing at first to learn using a new method that was not previously available, but as a result of its actual application, innovative methods of learning could be found to be possible if applied to the school."

"There should be an easy way to purchase the necessary tools for learning."

"Through the program, students were able to connect science and coding and also improve their ability to think in a more integrated way. And it was an opportunity to pay attention to the career path involved."

"I was able to conduct a really fun class by watching them succeed and help out with their desired works by directly controlling and creating the technological field that can be enjoyed by the development of science, instead of only exploring simple principles."

"As a teacher, I also enjoyed turning on the lights as much as I wanted to on the Flexible display, and the process of controlling with a smartphone was really new."

\section{REFERENCES}

[1] Korea Ministry of Government Legislation. (2018). An educational bill of mathematics, science and information education. [Online]. Available:

http://law.go.kr/nwRvsLsInfoR.do?lsNm=\&cptOfi=\&searchType=\&l sKndCd $=\&$ p_spubdt $=\& p \_e p u b d t=\& p \_s p u b n o=\& p \_$_epubno $=\&$ pageIn dex $=1 \& \operatorname{chrIdx}=0 \&$ sortId $=0 \& 1$ siSeq $=198221$

[2] Y. J. Shin and S. K. Han, "A study of the elementary school teachers' perception in STEAM (science, technology, engineering, arts, mathematics) education," Journal of Korean Elementary Science Education, vol. 30, no. 4, pp. 514-523, 2011.

[3] M. Sanders, "STEM, STEM, Education, STEM mania," The Technology Teacher (December/January 2009), pp. 20-26, 2009.

[4] Ministry of Education, Science and Technology, Future Korea Opens with Creative Human Resources and Advanced Technology, 2010.

[5] J. Tarnoff, "STEM to STEAM - Recognizing the value of creative skills in the competitiveness debate," The Huffington Post, 2010.

[6] J. Mae, TED Talks, 2002.

[7] Korea Foundation for the Advancement Science \& Creativity. (2017) A study on the development of creative convergence science education. [Online]. Available: http://www.gjue.ac.kr/gjue/preview/1496320313746/index.html

Copyright (C) 2019 by the authors. This is an open access article distributed under the Creative Commons Attribution License which permits unrestricted use, distribution, and reproduction in any medium, provided the original work is properly cited (CC BY 4.0).
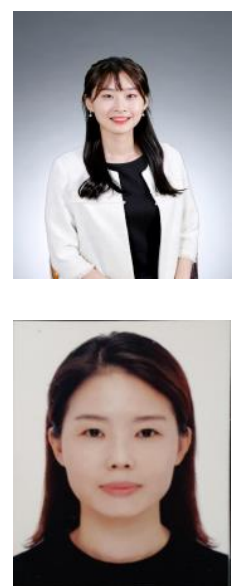

programming.
Hye Sun Song lives in Uijeongbu, Gyeonggi-Do, and her birth date is June 6, 1991. She received her B.E degree in elementary education from Gongju university of education in 2016. She is currently a postgraduate student in STEAM education from Gyeongin University of education. She is an elementary school teacher in Uijeongbu, Gyeonggi-Do.

Ji Young Lee lives in Seoul. She received the B.E degree in elementary education from Chuncheon University of Education in 2000. She is currently a postgraduate student in STEAM education from Gyeongin University of Education. She is an elementary school teacher in Uijeongbu, Gyeonggi-Do. Ms. Lee is interested in STEAM education program development using computer 


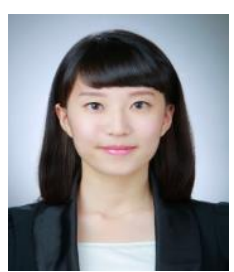

Yeon Jung Song was born in Korea on November 11, 1987. She received the B.E degree in elementary education and computer education from Korea National University of Education in 2012. She is an elementary school teacher in Uijeongbu, Gyeonggi-Do. She is currently a postgraduate student in STEAM education from Gyeongin University of Education. Ms. Song is interested in STEAM education program development using computer programming.

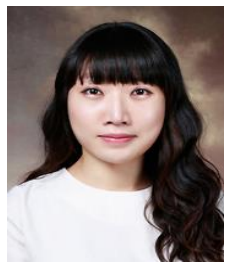

programming

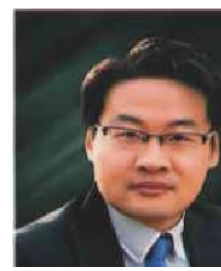

Seok Hui Kim received the B.E degree in electronical engineering from Korea University and the Ph.D. degree in computer education from Korea University in 1997, 2007, 2013. Since 2013, he has studied at creative computing research center. He is currently a teacher in elementary school. He is interested in STEAM education program development using computer programming.

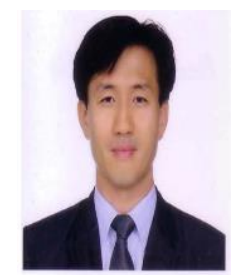

Heonchang Yu received the B.S., M.S., and Ph.D. degrees in computer science and engineering from Korea University, Seoul, Korea, in 1989, 1991, and 1994, respectively. He has been a professor of computer science and engineering with Korea University since 1998. Since 2015, he has been the vice president of Korea Information Processing Society, Korea. His research interests include STEAM-based computer education, cloud computing, and distributed computing. 